\title{
Reactivity of Clays Consummated in Côte d'Ivoire in Digestive Conditions: Bioavailability of Mineral Elements
}

\author{
Vamoussa Coulibaly ${ }^{1, *}$, N'dri Kouamé ${ }^{2}$, Atolé Brice Kedi ${ }^{3}$; Joseph $\mathrm{Sei}^{1}$, Samuel Oyetola ${ }^{1}$ \\ ${ }^{1}$ Laboratoire de Chimie des Matériaux Inorganiques, UFR SSMT, \\ Université Félix Houphouët-Boigny, 22 BP 582 Abidjan 22 (Côte d'Ivoire) \\ ${ }^{2}$ Laboratoire de Chimie des Matériaux Inorganiques, UFR SSMT, \\ Université Félix Houphouët-Boigny, 22 BP 582 Abidjan 22 (Côte d'Ivoire) \\ ${ }^{3}$ Laboratoire des sciences et technologies de l'environnement, UFR Environnement \\ Université Jean Lorougnon Guédé 12 BP V 25 DALOA 12 (Côte d'Ivoire) \\ *Corresponding author's email: coulibaly_vamoussa [AT] yahoo.fr
}

\begin{abstract}
In order to evaluate the impact of clay on the body during digestion, a study of the bioavailability of elements from clay minerals from Anyama and Bingerville (Abidjan district) was performed in vitro. A simulation of the destruction of a solid matrix in the human gastrointestinal tract was undertaken. The analysis of different juices after digestion revealed the presence of numerous inorganic elements essential for biological activity. Green clay of Anyama consisting of chlorite, illite and smectite, released more elements than those of Bingerville, the mineralogy of witch being dominated by kaolinite. The concentration of some ions ( $\mathrm{Al}, \mathrm{Co}, \mathrm{Ca}, \mathrm{Cu}, \mathrm{Fe}, \mathrm{Zn}, \mathrm{Pb}, \mathrm{Si}$ ) decreased during the transition from the step of the stomach $(p H=2.5)$ to that of the small intestine $(p H \approx 7)$. The proportions of zinc and copper in spite of decrease during the small intestine step, remain superior to the others. To the contrary, an increase was observed for $\mathrm{K}, \mathrm{Ni}$ and $\mathrm{P}$. Iron and calcium in this series were distinguished by their disappearance during the stage of the small intestine.
\end{abstract}

Keys word: clay minerals, trace elements, reactivity, bioavability, geophagy.

\section{INTRODUCTION}

Clays are materials containing many elements that can be beneficial or hazardous for humans, depending on their bioavailability and their impact on metabolic processes. For millennia, clays have been used in many fields, on all continents, due to their numerous properties. Some of these properties (absorption, antiseptic, antacid, healing, etc.), provide them many therapeutic and cosmetic functions. They are used internally, mainly for gastrointestinal care, or externally (Neli et $\boldsymbol{a l .}$. 2016), mainly in dermatology (Carretero, 2002, 2010). Thus, very present in the pharmacopoeia of natural or traditional medicines, clays are also used in "official" medicine under the form of pharmaceutical specialties (palygorskite, kaolinite or aluminum silicate, montmorillonite, beidellite ...). In addition, ingestion of soil or geophagia, also known as pica, is observed on all continents (Johns and Duquette, 1991; Abrahams and Parsons, 1996; Mahaney et al., 2000; Tateo et al., 2001; Saathoff et al., 2002; Nchito et al., 2004). However, in nature clays are associated with impurities and contain heavy metals which pose a danger in human internal use. Moreover, geophagy may contribute to intestinal parasitosis (Wong et al., 1991; Holland et al., 1995; Geissler et al., 1998) and mineral deficiencies (Horner et al., 1991; Moore and Sears, 1994; Trivedi, 2005). In Côte d'Ivoire as elsewhere, some pregnant women ingest clays for preventing nauseas due to hyper-salivation, against ulcer pain and also because of the aroma it gives off. According to Hunter, (1973); Vermeer and Ferrell, (1985), ingestion of clay would be a remedy against diarrhea and also intestinal parasites, since ingested particles protect the gastrointestinal epithelium (Moré et al., 1987). Clays are also used as antibacterial (Williams, 2017).To contribute to prevent the risks related to the use of clays without any control, a study of the bioavailability of minerals has been undertaken in vitro. In this experiment, a simulation of the destruction of a solid matrix in the human gastrointestinal tract was performed on some clays from Côte d'Ivoire. This study aims at predicting the nature and content of mineral elements that should be at the disposal of the body after digestion.

\section{MATERIALS AND METHODS}

\subsection{Materials}

Studied materials come from Anyama and Bingerville (district of Abidjan), respectively located in the north-east and south-east of Abidjan. These locations are in a sedimentary basin containing sand and clay formations (Tastet, 1979). Anyama's sample (named AVA) was taken on the outcrop and air-dried as that sold on the market. Bingerville's samples 
(named LBF, LRF, LVF, LMF, LJPF, and LJFF) were also collected on the deposit depending on the color and have undergone the same heat treatment as the marketed material called "Lokpo". That heat treatment consists in heating and roaster the material for 3 to 5 days in an oven built in clay and fueled with wood. This operation gives often a pleasant smell to the clay material. Different analyzes in previous studies have revealed the mineralogy. The sample of Anyama consists of chlorite (29.5\%), smectite (2.5\%) and illite (20.2\%) (Coulibaly $\boldsymbol{e t}$ al., 2013) while those of Bingerville are mainly composed by kaolinite (41 to 84\%), quartz (14 - 27\%), goethite (2 - 5\%) for all samples except LJFF (26\%) and illite (4-10\%) associated with the rutile trace (1\%) (Coulibaly et al., 2014).

\subsection{Methods}

\section{* Physicochemical characterization}

The specific surface areas of samples were determined by the BET method using nitrogen as a probe molecule to $77 \mathrm{~K}$.

For the measurement of $\mathrm{pH}, 4 \mathrm{~g}$ of sample were placed in $100 \mathrm{~mL}$ of distilled water. After one hour stirring, the $\mathrm{pH}$ of the sample is measured directly.

The measurement of the Cation Exchange Capacity (CEC) was performed by moving the exchangeable cations by cobalt hexammonium ions $\left[\mathrm{Co}\left(\mathrm{NH}_{3}\right)_{6}\right]^{3+}$ which gives orange solutions $(2.5<\mathrm{pH}<5.5)$. This method, simple and rapid, is very reliable because the cobalt hexammonium ion has a very high power for moving the exchangeable cations off the clays (Morel, 1957). The cobalt hexammonium ion in the supernatant was then titrated by colorimetry using a spectrophotometer Shimadzu UV 2100, and some of the displaced ions $\left(\mathrm{Na}^{+}, \mathrm{K}^{+}, \mathrm{Ca}^{2+}, \mathrm{Mg}^{2+}\right.$ and $\left.\mathrm{Al}^{3+}\right)$ were analyzed by atomic absorption.

Chemical analysis of clay samples and digestion solutions were carried out using a Perkin Elmer Elan 5000 quantometer equipped with a plasma ICP-MS according to the procedure described by Carignan $\boldsymbol{e t}$ al., (2001).

* Extraction Solution

The literature reveals several physiological extraction protocols in vitro (Cabral and Small, 1989; Tateo et al., 2001; Cave et al., 2003).

Among these, a modified method based on that of Cave et al., (2003) was used, because of its simplicity and the fact that the composition of the extraction liquid is closer to the composition of human gastric juice. The steps of the stomach and the small intestine were considered.

\section{* Stomach medium:}

A mixture of pepsin $(1.25 \mathrm{~g}$, Sigma Aldrich), sodium malate ( $0.50 \mathrm{~g}$, Sigma Aldrich), sodium citrate $(0.50 \mathrm{~g})$, lactic acid ( $420 \mu \mathrm{L}$, Sigma Aldrich), acetic acid $(500 \mu \mathrm{L}$ ) is completed to one liter with deionized water. The $\mathrm{pH}$ is adjusted to 2.5 with a concentrated solution of hydrochloric acid. Then, in a polypropylene bottle, one g of clay was contacted with 100 $\mathrm{mL}$ of this juice. The vials containing the mixture (simulated gastric fluid and the sample) were placed under stirring in a temperature regulated bath at $37^{\circ} \mathrm{C}$. After one hour at $37^{\circ} \mathrm{C}, 25 \mathrm{~mL}$ were withdrawn and filtered through a cellulose filter of 0.2 micrometers (Gelman) for analysis. This filtrate is the phase of the stomach.

\section{* Small Intestine medium:}

$25 \mathrm{~mL}$ of the solution were added to the initial gastric contents of the vial containing the mixture to maintain the initial solid/solution ratio. The conditions were then modified by adding a saturated solution of sodium bicarbonate to adjust the $\mathrm{pH}$ to 7. Then, bile salts (175 mg, Sigma Aldrich) and pancreatin $(50 \mathrm{mg}$, Sigma Aldrich) was added. The samples were placed in a stirred water bath. After two hours, $25 \mathrm{~mL}$ of supernatant were removed and filtered through a cellulose filter of $0.2 \mu \mathrm{m}$. This collection is the filtrate phase of the small intestine. Extracts collected at the two phases were then analyzed to identify and assess the proportions of different ionic species that may pass through the body.

According to Abraham et al., (2006), the ratio of one g per $100 \mathrm{~mL}$ can maintain the stability of $\mathrm{pH}$ and needs 2 hours to reach equilibrium.

\section{RESULTS}

\subsection{Characteristics of the samples}

\subsubsection{Chemical composition of the samples}

The sample of Anyama is poor in $\mathrm{Al}_{2} \mathrm{O}_{3}$ and generally richer than samples of Bingerville in $\mathrm{SiO}_{2}, \mathrm{Fe}_{2} \mathrm{O}, \mathrm{MgO}$ and $\mathrm{K}_{2} \mathrm{O}$ (Coulibaly et al; 2013, 2014).

Chemical analysis reveals that, except LJFF, all samples of Bingerville (Table 1) have relatively similar chemical composition. The $\mathrm{SiO}_{2}$ content range from 45.73 to $57.05 \%$, those of $\mathrm{Al}_{2} \mathrm{O}_{3}$, from 25.22 to $34.41 \%$, and trace amount of 
$\mathrm{Fe}_{2} \mathrm{O}_{3}, \mathrm{TiO}_{2}, \mathrm{Na}_{2} \mathrm{O}, \mathrm{K}_{2} \mathrm{O}$ and $\mathrm{MgO}$ are detected. Sample LJFF has high concentration of iron oxide (26.02\%) and lower concentrations of silica (42.71\%) and alumina (18.33\%).

Table 1: Chemical content in major elements in weight percent (n.d = not determined). (Coulibaly et al; 2013, 2014)

\begin{tabular}{llccccccccccc}
\hline Samples & Colour & $\mathbf{S i O}_{2}$ & $\mathbf{A l}_{2} \mathbf{O}_{3}$ & $\mathbf{F e}_{2} \mathbf{O}_{3}$ & $\mathbf{M n O}$ & $\mathbf{M g O}$ & $\mathbf{C a O}$ & $\mathbf{N a}_{2} \mathbf{O}$ & $\mathbf{K}_{2} \mathbf{O}$ & $\mathbf{T i O}_{2}$ & $\mathbf{P}_{2} \mathbf{O}_{\mathbf{5}}$ & $\mathbf{H}_{2} \mathbf{O}$ \\
\hline $\mathbf{A V A}$ & Green & 61.58 & 17.21 & 7.42 & 0.08 & 3.84 & 0.04 & 0.46 & 2.38 & 0.75 & n.d & 5.74 \\
$\mathbf{L B F}$ & White & 52.83 & 29.74 & 2.34 & n.d & 0.29 & n.d & 0.11 & 1.17 & 1.06 & 0.08 & 12.03 \\
$\mathbf{L R F}$ & Red & 51.06 & 30.18 & 4.48 & 0.00 & 0.22 & n.d & 0.11 & 1.16 & 1.13 & 0.06 & 11.97 \\
$\mathbf{L M F}$ & Brown & 56.55 & 25.44 & 4.25 & 0.01 & 0.36 & n.d & 0.08 & 1.01 & 1.10 & 0.08 & 11.46 \\
$\mathbf{L V F}$ & Purple & 45.73 & 34.41 & 4.92 & n.d & 0.07 & n.d & 0.06 & 0.57 & 1.12 & 0.09 & 13.12 \\
$\mathbf{L J P F}$ & Yellow & 55.33 & 27.81 & 3.97 & 0.00 & 0.24 & n.d & 0.06 & 0.77 & 0.94 & 0.21 & 11.40 \\
$\mathbf{L J F F}$ & Dark- & 42.71 & 18.33 & 26.02 & n.d & 0.14 & n.d & 0.05 & 0.63 & 0.87 & 0.12 & 11.69 \\
& yellow & & & & & & & & & & & \\
\hline
\end{tabular}

The elements identified as trace represent the majority of heavy metals, lanthanides and actinides. Samples contain some other heavy metals (cobalt, copper, molybdenum, zinc) (Coulibaly et al; 2013, 2014).

\subsubsection{Mineralogical and physicochemical characteristics}

The total surface area was $5.4 \mathrm{~m}^{2} / \mathrm{g}$ for the sample of Anyama, while those of Bingerville ranged from 26.8 to $43.0 \mathrm{~m} / \mathrm{g}$ (Table 2). These values are consistent with those reported in the literature (Guyo, 1969; Liétard, 1977). Except for samples LRF and LVF of Bingerville, the specific surface increases with the content of iron oxide (goethite), what is usual (Borggaard, 1982). Moreover, the $\mathrm{pH}$ measured ranged from 4.6 to 5.4, reflecting the acidity of the samples.

Table 2: Mineralogical and physicochemical characteristics of the samples (Coulibaly et al; 2013, 2014)

\begin{tabular}{lccccccccc}
\hline & \multicolumn{3}{c}{$\begin{array}{l}\text { Physicochemical } \\
\text { properties }\end{array}$} & \multicolumn{7}{c}{ Mineralogical composition (\%) } \\
& $\mathrm{pH}$ & $\begin{array}{l}\mathrm{S}_{\mathrm{BET}} \\
\left(\mathrm{m}^{2} \cdot \mathrm{g}^{-1}\right)\end{array}$ & Kaolinite & Illite & Chlorite & Smectite & Quartz & Goethite & Rutile \\
\hline AVA & 5.4 & 5.4 & - & 20.17 & 29.53 & 2.5 & 40.53 & - & 1.00 \\
LBF & 4.8 & 35.7 & 66.79 & 9.73 & - & - & 17.06 & 2.34 & 1.06 \\
LRF & 5 & 35.05 & 67.98 & 9.66 & - & - & 14.77 & 4.48 & 1.13 \\
LVF & 4.6 & 26.8 & 83.61 & 4.74 & - & - & 4.3 & 4.92 & 1.12 \\
LMF & 4.7 & 39.8 & 57.06 & 8.38 & - & - & 25.96 & 4.25 & 1.10 \\
LJFF & 4.8 & 43 & 41.86 & 5.28 & - & - & 20.67 & 26.02 & 1.00 \\
LJPF & 4.7 & 35.8 & 65.02 & 6.44 & - & - & 21.87 & 3.97 & 1.00 \\
\hline
\end{tabular}

The CEC values were determined both from the cobalt hexammonium consumption and from the sum of the cations released in the solution. Thus, in the absence of other phenomena, the CEC values deduced from the two methods would have to be close each others. The obtained results are given in table 3. Two points must be pointed out:

(i) In most of the cases, (except for sample AVA), the CEC determined by adsorption of cobalt hexammomium ions is greater than the sum of ions titrated in the solution, what suggested that, other ions that those analyzed assume a significant part of the ionic compensation (e.g. Mn, Fe...);

(ii) (ii) Compensation in samples LBF, LRF, LVF, LMF, LJFF, and LJPF, is mainly provided by aluminum, whereas for the sample AVA, CEC is supported by Mg and Al. Aluminum released could be, in part, attributed to the dissolution of poorly crystalline aluminum hydroxide, as noticed by Andji et al., (2009) for outcrop clays from the same neighborhood. The high mobility of aluminum indicates that the lateritic weathering profile is not at equilibrium. 
Table 3: Cation Exchange Capacities (CEC) expressed in meq/100g of solid.

\begin{tabular}{lccccccc}
\hline Sample & Na & K & Ca & Mg & Al & $\begin{array}{c}\text { CEC, sum of } \\
\text { released cations }\end{array}$ & $\begin{array}{c}\text { CEC, cobalt } \\
\text { hexammonium }\end{array}$ \\
\hline AVA & 0.08 & 0.27 & 0.73 & 3.55 & 2.63 & 7.26 & 7.06 \\
LBF & 0.06 & 0.17 & 0.24 & 0.24 & 5.86 & 6.57 & 9.66 \\
LRF & 0.10 & 0.14 & 0.25 & 0.19 & 3.45 & 4.13 & 9.78 \\
LVF & 0.07 & 0.05 & 0.14 & 0.07 & 2.95 & 3.28 & 6.92 \\
LMF & 0.11 & 0.30 & 0.38 & 0.38 & 6.65 & 7.82 & 10.96 \\
LJFF & 0.05 & 0.12 & 0.12 & 0.12 & 1.80 & 2.21 & 3.45 \\
LJPF & 0.08 & 0.18 & 0.15 & 0.15 & 5.09 & 5.65 & 8.6 \\
\hline
\end{tabular}

\subsection{Reactivity in digestive conditions}

Many ions are involved in human metabolism (Table 4). The concentrations of various chemical species extracted after the two stages of digestion were measured (Table 5).

Table 4: Specific functions of essential minerals and trace elements (mainly from Gomes and Silva, 2007)

\begin{tabular}{|c|c|}
\hline Element & Specific functions \\
\hline $\mathbf{C a}$ & $\begin{array}{l}\text { Essential for developing and maintaining healthy bones and teeth; assists in blood clotting, } \\
\text { muscle contraction and nerve transmission; helps reduce risk of osteoporosis. }\end{array}$ \\
\hline Mg & Activates over 100 enzymes and helps nerves and muscles function. \\
\hline $\mathbf{K}$ & $\begin{array}{l}\text { Regulates heartbeat, maintains fluid balance and helps muscles contraction, has an important } \\
\text { role in nervous transmission. }\end{array}$ \\
\hline $\mathbf{F e}$ & Essential for red blood cells formation and function; important for brain function. \\
\hline $\mathbf{C r}$ & $\begin{array}{l}\text { Aids in glucose metabolism and regulates blood sugar, is an acute cytotoxic poison under its } \\
\text { hexavalent form. }\end{array}$ \\
\hline Co & Promotes the formation of red-blood cells. \\
\hline $\mathbf{C u}$ & $\begin{array}{l}\text { Promotes the formation of red blood cells and connective tissue ; acts as a catalyst to store and } \\
\text { release iron to help form haemoglobin ; contributes to central nervous system function. In } \\
\text { excess can be poisonous and lead to steatosis in chronic poisoning. }\end{array}$ \\
\hline $\mathbf{P}$ & $\begin{array}{l}\text { Works with Ca to develop and maintain strong bones and teeth; enhances the use of other } \\
\text { nutrients. }\end{array}$ \\
\hline $\mathbf{Z n}$ & $\begin{array}{l}\text { Essential component of more than } 200 \text { enzymes involved in digestion, metabolism, reproduction } \\
\text { and wound healing. }\end{array}$ \\
\hline Si & Essential for normal bone growth, and for proper integrity of the skin. \\
\hline Al & Cytotoxic and suspected to be involved in Alzeimer's desease. \\
\hline
\end{tabular}


Table 5: Chemical analysis $(\mathrm{mg} / \mathrm{L})$ of the digestion solutions of the two steps: stomach $(\mathrm{pH}=2.5)$ and small intestine $(\mathrm{pH}=7)$

\begin{tabular}{|c|c|c|c|c|c|c|c|c|c|c|c|c|c|c|c|c|}
\hline \multirow{2}{*}{ Clay sample } & \multirow{2}{*}{$\begin{array}{l}\text { Digestion } \\
\text { solutions }\end{array}$} & \multicolumn{15}{|c|}{ Element concentration, mg/L } \\
\hline & & Co & $\mathrm{Cr}$ & $\mathbf{C u}$ & $\mathbf{N i}$ & $\mathbf{P b}$ & $\mathbf{U}$ & Zn & Al & $\mathbf{S i}$ & $\mathbf{F e}$ & Mn & Mg & $\mathbf{C a}$ & $\mathbf{K}$ & $\mathbf{p}$ \\
\hline \multirow{2}{*}{ AVA } & Stomach & 0.18 & 0.06 & 0.79 & 0.04 & 0.01 & - & 0.34 & 5.20 & 0.71 & 1.60 & 0.18 & 6.66 & 8.65 & 6.08 & 5.66 \\
\hline & Small intestine & 0.15 & 0.18 & 0.40 & 0.03 & - & - & 0.13 & 20.40 & 1.20 & - & 0.13 & 4.56 & - & 10.30 & 5.42 \\
\hline \multirow{2}{*}{$\mathbf{L B F}$} & Stomach & 0.01 & 0.04 & 0.12 & - & - & - & 0.14 & 8.40 & 1.06 & 0.50 & 0.01 & 1.31 & 2.52 & 5.40 & 3.60 \\
\hline & Small intestine & - & 0.11 & 0.17 & 0.01 & - & - & 0.10 & 1.60 & 0.66 & - & 0,01 & 1.31 & - & 8.23 & 3.73 \\
\hline \multirow{2}{*}{ LRF } & Stomach & 0.01 & 0.03 & 1.69 & - & - & - & 0.12 & 8.00 & 1.58 & 0.40 & 0,01 & 1.32 & 2.25 & 5.29 & 3.27 \\
\hline & Small intestine & 0.01 & - & 1.02 & 0.01 & - & - & 0.08 & 2.43 & 0.91 & - & 0,01 & 0.87 & - & 6.81 & 4.65 \\
\hline \multirow{2}{*}{ LJPF } & Stomach & - & 0.03 & 0.11 & - & - & - & 0.13 & 7.30 & 1.37 & 0.40 & 0,01 & 1.50 & 3.94 & 5.26 & 3.10 \\
\hline & Small intestine & - & - & 0.08 & 0.02 & - & - & 0.12 & 1.65 & 0.68 & - & 0,01 & 1.27 & - & 7.51 & 3.88 \\
\hline \multirow{2}{*}{ LJFF } & Stomach & 0.01 & 0.03 & 0.22 & - & - & - & 0.15 & 6.60 & 3.16 & 1.60 & 0,01 & 1.16 & 2.21 & 5.22 & 1.14 \\
\hline & Small intestine & - & - & 0.18 & 0.01 & - & 0.01 & 0.09 & 1.55 & 1.50 & - & - & - & - & 7.43 & 3.62 \\
\hline \multirow{2}{*}{ LMF } & Stomach & 0.01 & 0.03 & 0.12 & 0.01 & - & - & 0.16 & 8.40 & 1.00 & 0.50 & - & 1.48 & 2.58 & 5.66 & 3.19 \\
\hline & Small intestine & - & - & 0.13 & 0.01 & - & - & 0.10 & 2.72 & 0.55 & - & - & 0.99 & - & 6.99 & 5.02 \\
\hline \multirow{2}{*}{ LVF } & Stomach & 0.01 & 0.03 & 0.19 & - & 0.01 & - & 0.72 & 6.10 & 1.59 & 0.20 & - & 1.06 & 1.80 & 6.75 & 3.23 \\
\hline & Small intestine & 0.01 & - & 0.10 & - & - & - & 0.10 & 1.57 & 1.03 & - & - & 1.3 & - & 9.55 & 5.01 \\
\hline
\end{tabular}




\subsubsection{Analysis of digestion solutions of the stomach}

In the stomach environment, the digestion of clays leads to the release of many mineral elements whose content varies from one clay to another. Thus, more generally the elements $\mathrm{Al}(5.15$ to $8.38 \mathrm{mg} / \mathrm{L}), \mathrm{Si}(0.71$ to $3.16 \mathrm{mg} / \mathrm{L}), \mathrm{Fe}(0.18$ to $1.63 \mathrm{mg} / \mathrm{L}), \mathrm{Mg}(1.06-6.66 \mathrm{mg} / \mathrm{L}), \mathrm{Ca}(1.8$ to $8.65 \mathrm{mg} / \mathrm{L}), \mathrm{K}(5.22$ to $6.08 \mathrm{mg} / \mathrm{L})$ and $\mathrm{P}(1.14$ to $5.66 \mathrm{mg} / \mathrm{L})$ were released in significant amounts in the stomach digestion solutions, the contents of other elements such as $\mathrm{Cr}(0.03$ to $0.06 \mathrm{mg} / \mathrm{L}), \mathrm{Zn}(0.12$ to $0.72 \mathrm{mg} / \mathrm{L})$ and $\mathrm{Mn}(0$ to $0.18 \mathrm{mg} / \mathrm{L})$ were quite low. The concentrations of $\mathrm{Co}, \mathrm{Ni}, \mathrm{Pb}$ and $\mathrm{U}$ were practically zero. They can be considered as not being bioavailable in this environment model.

The maximum observed for $\mathrm{Fe}, \mathrm{Mn}, \mathrm{Mg}, \mathrm{Ca}, \mathrm{K}$ and $\mathrm{P}$ were in the sample AVA dominated by chlorite and illite. For the elements $\mathrm{Al}, \mathrm{Si}, \mathrm{Zn}$ and $\mathrm{Cu}$, the high levels were observed in samples of Bingerville dominated by kaolinite.

\subsubsection{Analysis of digestion solutions of the small intestine}

The digestion of clays in the small intestine juice leads to the release of $\mathrm{Al}(1.55-20.43 \mathrm{mg} / \mathrm{L}), \mathrm{Si}(0.55-1.5 \mathrm{mg} / \mathrm{L}), \mathrm{Mg}$ $(0-4.56 \mathrm{mg} / \mathrm{L}), \mathrm{K}(6.81-10.3 \mathrm{mg} / \mathrm{L})$ et $\mathrm{P}(3.62-5.42 \mathrm{mg} / \mathrm{L})$ and low concentrations of $\mathrm{Cu}(0.08-0.5 \mathrm{mg} / \mathrm{L})$ et $\mathrm{Zn}(0.08-0.13$ $\mathrm{mg} / \mathrm{L})$.

Furthermore, the material balance of the two digestion steps indicated that precipitation phenomena of $\mathrm{Al}, \mathrm{Si}, \mathrm{Ca}, \mathrm{and} \mathrm{Mg}$ occur in small intestine digestion solutions of all Bingerville clays, while the amount of aluminum released from AVA sample was about four fold that of stomach digestion solution. Likewise, $\mathrm{Cr}$ concentration was three higher in the intestine digestion solutions of the samples AVA. The precipitation reactions concern also $\mathrm{Ca}$ in AVA sample and $\mathrm{Fe}$ in all clays.

$\mathrm{Co}, \mathrm{Cr}, \mathrm{Pb}, \mathrm{U}, \mathrm{Fe}, \mathrm{Mn}$ and $\mathrm{Ca}$ where the concentrations were practically nil, may be considered as not bioavailable in this medium.

High levels of $\mathrm{Cu}, \mathrm{Zn}, \mathrm{Al}, \mathrm{Mg}, \mathrm{K}$ and $\mathrm{P}$, were observed in the sample AVA while for Si element, the maximum was observed in the sample LJFF from Bingerville.

\subsubsection{Comparative study of bioavailability of elements in the two models and environments in the two localities studied clays.}

In general, the mineral elements released by Bingerville samples in the medium of the stomach were more important than those relaesed in the medium of the small intestine, with the exception of elements $\mathrm{K}$ and $\mathrm{P}$ (figure 1).

For the AVA sample, this exception extended to the elements $\mathrm{Si}$ and $\mathrm{Al}$ in addition to elements $\mathrm{K}$ and $\mathrm{P}$. Indeed, the rate of $\mathrm{Al}$ released by this sample in the middle of the small intestine model is 4 times greater than that released into the medium model of the stomach while for $\mathrm{Si}$, this factor is of the order of 2.

Moreover, the rates of the elements $\mathrm{Al}, \mathrm{Si}, \mathrm{Fe}, \mathrm{Mn}, \mathrm{Mg}, \mathrm{Ca}, \mathrm{K}$ and $\mathrm{P}$ released by the AVA sample were higher than those of Bingerville samples. So AVA sample may be considered as a micronutrient and macronutrient provider.

For copper, the highest rate was that of sample LRF despite the fact that LMF and LJFF clays contain more copper. While for zinc, the highest amount was observed for sample LVF of Bingerville.

The concentrations released for $\mathrm{Co}, \mathrm{Cr}, \mathrm{Ni}, \mathrm{Pb}, \mathrm{U}$ and $\mathrm{Mn}$ in both the stomach and in the small intestine were negligible.

The sample LJFF which was richer in iron $\left(26 \% \mathrm{Fe}_{2} \mathrm{O}_{3}\right)$ released the same amount of $\mathrm{Fe}$ as the sample AVA of Anyama. The lowest rate was in the sample LVF. These observations lead to assume that the iron released is a part of structure of the clay and not of iron oxyhydroxides such as goethite observed in large quantities in the sample LJFF. 

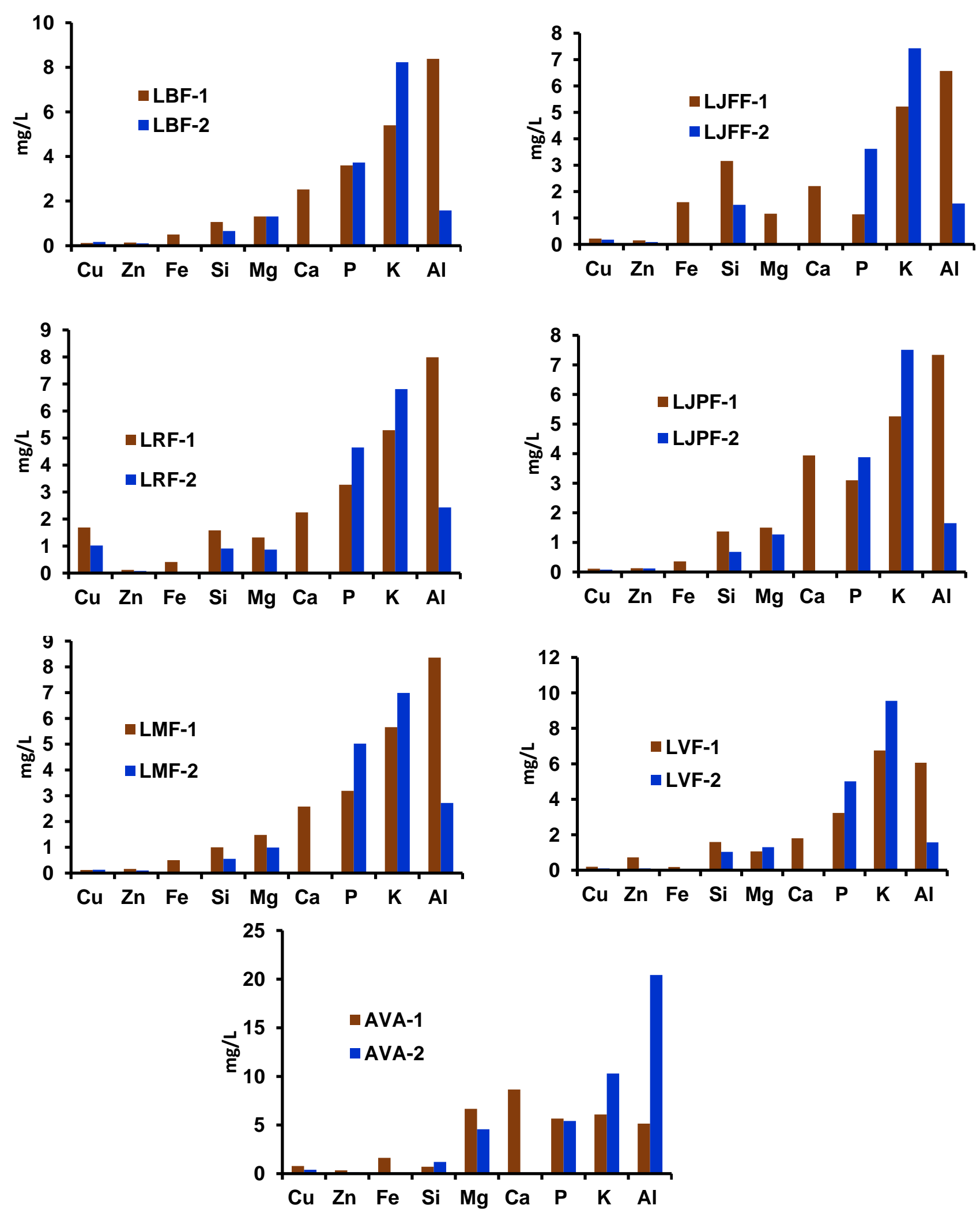

Figure 1: Comparative study of bioavailability in the medium of stomach and small intestine Stomach; : Small intestine 


\subsubsection{Discussion}

The extracts contain $\mathrm{Cr}, \mathrm{Cu}, \mathrm{Fe}, \mathrm{Zn}, \mathrm{Co}, \mathrm{Mn}$ (trace elements), $\mathrm{Ca}, \mathrm{K}, \mathrm{Mg}, \mathrm{P}$ (macronutrients) and other ions such as $\mathrm{Pb}$, $\mathrm{U}$, which could be a source of nutrients or danger for the human body, depending on their concentration. In vitro studies (Abrahams et al., 2006; Johns and Duquette, 1991; Hooda et al., 2002, 2004; Smith et al., 2000; Owumi and Oyelere, 2015) used to assess the release in the gastrointestinal juice of certain elements such as $\mathrm{Ca}, \mathrm{Cu}, \mathrm{Fe}, \mathrm{Mg}, \mathrm{Mn}$ and Zn. Similarly, Mascolo et al., (1999, 2004) during experiments in vivo performed on rats fed with clays, toxic elements were detected in the urine and in various organs (kidney, liver, heart, brain). They concluded that the presence of these elements in the urine indicated that the absorption process occurred after ingestion of clay, causing a gradual increase of metals in urine and blood. Ion concentration is generally higher in the stomach extracts. This has been observed by many authors (Abrahams et al., 2006; Wragg and Cave, 2003; Ruby et al., 1996, Smith et al., 2000) who attributed it to several factors namely:

- the effect of complex formation with pancreatic / bile salts,

- the particle size and mineralogy,

- the kinetics of dissolution,

- the $\mathrm{pH}$ of the medium.

According to Ruby et al., (1999), the mobilization of the elements was higher in the stomach and thus represented the maximum amount of ions that can be absorbed. The fact that the ions are therefore more released in the stomach environment $(\mathrm{pH}=2.5)$, than in the small intestine could be explained by the acidic environment of the stomach, more efficient for mineral solubilization under cationic forms. The transition from the stomach to the small intestine is accompanied by an increase in $\mathrm{pH}(\mathrm{pH} \approx 7)$. According to Ruby et al., (1992, 1996), Oomen et al., (2003), following the increase in $\mathrm{pH}$, precipitation reactions occur. Those reactions lead to lower rates of dissolved and available elements for absorption during their transition through the intestinal epithelium. This phenomenon was stronger for $\mathrm{Fe}$ and $\mathrm{Ca}$ in the medium of the small intestine. According to Ruby et al., (1999) and Schroder et al., (2003), the cations were more affected by the rise in $\mathrm{pH}$ in the small intestine than the anions. In fact, in neutral or weakly alkaline conditions, iron and/or calcium hydroxides were formed, making the corresponding ions unavailable. A study of clay samples (high $\mathrm{pH}$ and CEC) showed retention of ions already available in the gastrointestinal juice (Hooda et al., 2002). Samples of this study had a low $\mathrm{pH}$ and low CEC. It is therefore difficult to conclude on the bioavailability of these two ions since other factors such as the physiological conditions of the individual (age, fatness, nutritional status...) act on the gastrointestinal $\mathrm{pH}$. However, the concentrations of these ions were higher in the gastric juice, accessibility were high therefore potentially bioavailable because, according to William, (1999), the ions detected in the gastric juice are bioavailable as potentially absorbable. According to Oomen et al., 2002, the human gastrointestinal tract is made up of a number of compartments where the ingested soil undergoes a series of reactions in which the time, the composition of the fluid and the $\mathrm{pH}$ of the reaction vary. Fe ions and $\mathrm{Ca}$ may be bioavailable if the step of the intestine was held at a $\mathrm{pH}$ lower than that of the experiment. The concentrations of $\mathrm{Cu}$ and $\mathrm{Zn}$ were distinguished from other ionic species; this reflects that both the ions were more bioavailable than others in different samples. The concentrations of $\mathrm{Cu}$ and $\mathrm{Zn}$ in the different samples were generally $0.1 \mathrm{mg} / \mathrm{L}$ minimum. Regarding other trace elements ( $\mathrm{Cr}$ and $\mathrm{Co}$ ) only two samples (LBF, AVA) released more than $0.1 \mathrm{mg} / \mathrm{L}$. Other samples except LJFF and LJPF have released a few tens of $\mu \mathrm{g} / \mathrm{L}$. AVA extracts contain the highest concentrations of the various ionic species which can be explained by the mineralogical composition that consists mainly of chlorite and smectite, the mineral chemistry of which is more complicated. Indeed, compared to kaolinite, chlorite and smectites are more easily dissolved in an acid medium. K concentration ranging from 5.7 to 6.1 $\mathrm{mg} / \mathrm{L}$ was the highest but was not dangerous because it was lower than toxicity limit (12 mg/L- European standards) in water intended for human consumption. The hypothesis that the ingestion of clay could provide micronutrients has also been demonstrated in numerous studies (Abrahams and Parsons, 1997, John and Duquette, 1991, Smith et al., 2000). However, even if the geophagia causes the release of nutrients potentially available to the body, it also carries risks. Gelfand et al., (1975) found in five patients hyperkalemia (excess of potassium) due to excessive ingestion of clay. Moreover Hooda et al., 2004 showed that the ingestion of clay could cause a reduction in the absorption of nutrients already bioavailable, especially micronutrients such as $\mathrm{Fe}, \mathrm{Cu}$ and $\mathrm{Zn}$. Trivedi et al., (2005) reported a case of hypokalemia in a pregnant woman after ingestion of clay. Cases of iron deficiency trained by geophagia have been reported by various studies (Garnier et al., 2008; Minnich et al., 1968; Nchito et al., 2004). According to the limits set by the World Health Organization (WHO), the concentrations of different elements were not dangerous for the human body as their amounts were too low.

The high levels of aluminum and silicon observed in the different samples reflect the release of these elements from the octahedral and tetrahedral layers after acid attack (Cabrera and Talibudeen, 1978; 1979). This high aluminum content can be dangerous because, according to Roig et al. (2006), the aluminum would be the cause of certain diseases, such as Alzheimer's disease. However, the aluminum released, pass into the small intestine where it can: 
- Either precipitate as aluminum hydroxide by the action of gastric juices;

- Either bind to organic molecules. In the model environment of the small intestine, the reduction of the aluminum content is due to the increase of $\mathrm{pH}$. Indeed, the increase in $\mathrm{pH}$ in the gut to earlier studies in rats (Cochran et al., 1993; Cunat et al., 2000), leads to the precipitation of aluminum dissolved by the pancreatic and biliary secretions in different forms such as aluminum hydroxide. According to Owumi and Oyelere (2015), ingestion of clay would be a danger to pregnant women and their fetuses because of the high levels of aluminum. This is only partly true, because, under high $\mathrm{pH}$ conditions alumunium hydroxide is formed. Thus, the formation of hydroxide reduces the level of bioavailable aluminum. The presence of silicon can cause the formation of metastable aluminosilicates which are then excreted in the feces; this would limit the toxicity of aluminum (Powell and Thompson, 1993). During a study on rats fed with kaolinite, Chaumande (2011), observed the absorption of aluminum in the small intestine. According Powell and Thompson (1993), part of the dissolved aluminum, may bind to organic molecules of gastric juices and become soluble. Then, soluble aluminum is absorbable in small quantities in the intestinal wall. Aluminum absorbed into the systemic circulation is bound to transport proteins such as transferrin and albumin (Cochran et al., 1993; Powell et al., 1994). This fixing of aluminum leads to anemia observed in individuals practicing Geophagy (Geissler et al., 1998).

\section{CONCLUSION}

The specific surface areas determined for samples from Bingerville $\left(26-43 \mathrm{~m}^{2} / \mathrm{g}\right)$ are large enough, then these samples might have a high adsorption capacity. They can be used in the treatment of diarrhea or cases of poisoning; to the contrary they would not be associated with drugs because clays could alter their active ingredients. The sample of Anyama has a surface area of $5 \mathrm{~m}^{2} / \mathrm{g}$. The CEC of the samples is between 3.45 and $10.96 \mathrm{meq} / 100 \mathrm{~g}$. The compensation is usually provided by aluminum, depicting a high mobility of this element. The presence of oxides in the samples influences the mobility of certain ionic species. In addition to the microbiological studies to be undertaken, it is necessary to perform a sieve before internal use to extract possible coarse particles including quartz grains. Moreover, the experiments in this study allow forecasting the potential bioavailability of different elements. Element concentrations released from the sample AVA are higher than those released by the samples from Bingerville. Levels are relatively more important for $\mathrm{Al}, \mathrm{Si}, \mathrm{Fe}, \mathrm{Mn}, \mathrm{Mg}, \mathrm{Ca}, \mathrm{K}$ and $\mathrm{P}$. In samples from Bingerville, the elements released $\mathrm{Co}, \mathrm{Cu}, \mathrm{Zn}, \mathrm{Pb}, \mathrm{Fe}$ and $\mathrm{Ca}$, have a high mobility in the stomach and almost zero in the small intestine. An increase in $\mathrm{pH}$ in the small intestine caused the formation of iron and/or calcium hydroxide or a re-adsorption of elements. Their mobility strongly depends on the $\mathrm{pH}$ of the medium. Mobility of toxic elements such as $\mathrm{Pb}$ and $\mathrm{U}$ is very low, not exceeding one $\mu \mathrm{g}$ per gram of clay, thus ingestion of different samples has no danger.

\section{ACKNOWLEDGMENTS}

We thank all the staff of the Laboratoire Interdisciplinaire des Environnements Continentaux (Lorraine University) of Nancy (France), for its invaluable help to the realization of these works

\section{REFERENCES}

- Abrahams P.W., Parsons J.A., 1996. Geophagy in the tropics: a literature review. Geographical Journal 162, 63-72.

- Abrahams P.W., Parsons J.A., 1997. Geophagy in the tropics: an appraisal of three geophagical materials. Environmental Geochemistry and Health 19, 19-22.

- Abrahams P.W., Follansbee M.H., Hunt A., Smith B., Wragg J., Barry Smith, Joanna Wragg, 2006. Iron nutrition and possible lead toxicity: An appraisal of geophagy undertaken by pregnant women of UK Asian communities. Applied Geochemistry, 21, 98-108

- Andji Y.Y.J, Abba-Touré A., Kra G. and Yvon J., 2009. Variability of clays from Gounioube deposit (Ivory Coast). Journal of Applied Sciences, 9: 1238-1247.

- Borggaard O. K., 1982. The influence of iron oxide on the surface area of soil. Journal of. Soil Science, 33: 443449.

- Cabral D.J., Small D.M., 1989. Physical chemistry of bile. In: Shultz, S.G. (Ed.), Handbook of Physiology: The Gastrointestinal System III Section. Waverly Press, Baltimore.

- Cabrera F., Talibudeen O. 1978. The release of aluminium from aluminosilicate minerals. I. Kinetics. Clay. Clays and Clay Minerals, 26, 434-440. 
- Cabrera F., Talibudeen O. 1979. The release of aluminum from aluminosilicate minerals; II, Acid-base potentiometric titrations. Clay. Clays and Clay Minerals, 27, 113-118.

- Carignan J., Hild P., Mevelle G., Morel J., Yeghicheyan D. (2001). Routine analysis of trace elements in geological samples using flow injection and low pressure on-line liquid chromatography coupled to ICP-MS. A study of geological reference materials BR, DR-N, UB-N AN-G and GH. Geostandards and Geoanalytical Research. 25, 187-198.

- Carretero M. I., 2002. Clay minerals and their beneficial effects upon human health: a review. Applied Clay Science, 21, 155 - 163

- Carretero M. I. et Pozo M., 2010. Clay and non-clay minerals in the pharmaceutical and cosmetic industries. Part II. Active ingredients. Applied Clay Science, 47, 171-181

- Cave M. R., Wragg J., Palumbo B., Klinck B. A., 2003. Measurement of the Bioaccessibility of Arsenic in UK Soils. Environment Agency, R\&D Technical Report, P5-062/ TR02.

- Chaumande B., 2011. Apport des analyses protéomique et métalloprotéomique pour l'étude de la géophagie. Thèse de l'Université de Strasbourg, $241 \mathrm{p}$

- Cochran M., Goddard G., Ramm G., Ludwigson N., Mrshall J., Halliday J. 1993. Absorbed aluminium is found with two cytosolic protein fractions, other than ferritin, in the rats duodenum. Gut, 34: 643-646.

- Coulibaly V., Sei J., Koffi K. L., Oyetola S., Jdid E.-A. and Thomas F. (2014) Mineralogical and Chemical Characteristics of Clays Consumed in the District of Abidjan (Côte D'Ivoire). Materials Sciences and Applications, 5, 1048-1059. http://dx.doi.org/10.4236/msa.2014.514108

- Coulibaly V., Sei J., Oyetola S., Jdid E.A.,Thomas F., Yvon J. (2013). Mineralogy and physicochemical properties of the green clay of Anyama (Côte d'ivoire) used up for its healing properties. European Journal of Science Research, 99, (2), 261-270.

- Cunat L., Lanhers M. C., Joyeux M., Burnel D. (2000). Bioavailability and intestinal absorption of aluminum in rats: effects of aluminum compounds and some dietary constituents. Biological Trace Element Research, 76, 3155.

- Garnier Christophe von, Holger Stünitz, Michael Decker, Edouard Battegay et Andreas Zeller, 2008. Pica and refractory iron deficiency anaemia: a case report, Journal of Medical Case Reports

- Gelfand M. C., Zarate A., Knepsheild J. H., 1975. A cause of lifethreatening hyperkalemia in patients with chronic renal failure. Journal of the American Medical Association; 234:738 -740.

- Geissler P. W., Mwaniki D., Thiongo F., Michaelsen K. F., Friis H., 1998. Geophagy as a risk factor for geohelminth infections: A longitudinal study among Kenyan primary school children. Transactions of the Royal Society for Tropical Medicine and Hygiene, 92, 7-11.

- Gomes C. S., Silva J. B., 2007.Minerals and clay minerals in medical geology, Applied Clay Science 36, 4-21

- Guyot J., 1969. Mesure des surfaces spécifiques des argiles par adsorption. Annales Agronomiques 1969; 20: 33-359

- Holland C.V., O'Lorcain P., Taylor M. R. H., Kelly A., 1995. Sero-epidemiology of toxocariasis in school children. Parasitology 110, 535-545.

- Hooda P. S., Henry C. J., Seyoum T. A., Armstrong L. D., Fowler M. B., 2002. The potential impact of soil ingestion on human mineral nutrition. Environmental Geochemistry and Health 24, 305-319.

- Hooda P. S., Henry C. J. K., Seyoum T. A., Armstrong L. D. M., Fowler M. B., , 2004. The potential impact of soil ingestion on human mineral nutrition. Science of the Total Environment, 333, 75- 87

- Horner R., Lackey C., Kolasa K., 1991. Pica practices of pregnant women. Journal of the American Dietic Association 91, 34-38.

- Hunter J. M. 1973: Geophagy in Africa and in the United States: a culture-nutrition hypothesis. Geographical. Revew., 63, 170-195.

- Johns T., Duquette D., 1991. Detoxification and mineral supplementation as functions of geophagy. American Journal of Clinical. Nutrition, 53, 448-456. 
- Liétard O. 1977. Contribution à l'étude des propriétés physicochimiques cristallographiques et morphologiques des kaolins. Thèse d'état ès sciences physiques, INPL Nancy. 322 pp. and annexes.

- Mascolo N., Summa V., Tateo F., 1999. Characterization of toxic elements in clays for human healing use. Appied Clay Science 15, 491-500.

- Mascolo N., Summa V., Tateo F., 2004. In vivo experimental data on the mobility of hazardous chemical elements from clays. Applied Clay Science 25, 23-28.

- Mahaney W. C., Milner M.W., Mulyono H. S., Hancock R. G.V., Aufreiter S., Reich M., Wink M., 2000. Mineral and chemical analyses of soils eaten by humans in Indonesia. International Journal of Environmental Health Research 10, 93-109.

- Minnich V., Okcuoglu A., Tarcon Y., Arcasoy A., Cin S., Yorukoglu O., Randa F., Demirag B., 1968. Pica in Turkey. II effect of clay upon iron absorption. The American Journal of Clinical Nutrition 21, 78-86.

- Moore D. F., Jr. Sears D. A., 1994. Pica, iron deficiency, and the medical history. American Journal of Medicine 97, 390-393.

- $\quad$ Morel R., 1957, Thèse Doct. Scien., Paris, 200p

- Morel R., 1996, Les sols cultivés, Ed. Lavoisier, Paris,

- Moré J., Bénazet F., Fioramonti J. and Droy-Lefaix M.-T. 1987. Effects of treatment with smectite on gastric and intestinal glycoproteins in the rat: A histochemical study. Histochemical Journal. 19, 665-670.

- Neli G., Maria L. M., Carmen P. G., José L. L., Nastja R. S., Matej D., Nives K., 2016. The mineralogical, geochemical, and thermophysical characterization of healing saline mud for use in pelotherapy. Applied Clay Science, 135, 119-128

- Nchito M., Geissler P.W., Mubila L., Friis H., Olsen A., 2004. Effects of iron and multimicronutrient supplementation on geophagy: a two-by-two factorial study among Zambian schoolchildren in Lusaka. Transactions of the Royal Society of Tropical Medicine and Hygiene 98, 218-227.

- Oomen A. G., Hack A, Minekus M, Zeijdner E, Schoeters G, Verstraete W, Von de Wiele T, Wragg J, Rompelberg C. J. M., Sips A., Wijnen J. H. V., 2002. Comparison of five in vitro digestion models to study the bioaccessibility of soil contaminants. Environmental Science and Technology 36, 3326-3334

- Oomen A. G., Sips A. J. M., Tolls J., Van den Hoop M. A. G. T., 2003. Lead Speciation in Artificial Human Digestive Fluid, Archives of Environmental Contamination and Toxicology 44, 107-115

- Owumi, S. E., Oyelere, A. K., 2015. Determination of metal ion contents of two antiemetic clays use in Geophagy. Toxicology Reports 2, 928-932

- Powell J. J., Thompson R. P. H. 1993. The chemistry of aluminium in the gastrointestinal lumen and its uptake and absorption. Proceedings of the Nutrition Society, 52, 241-253.

- Powell J. J., Ainley C. C., Evans R., Thompson R. P. H. 1994. Intestinal perfusion of dietary levels of aluminium - Association with the lumen. Gut, 35, 1053-1057.

- Rateau J.-G., Morgant G., Droy-Priot M.-T. and Parier J.-L. 1982. A histological, enzymatic and waterelectrolyte study of the action of smectite, a mucoprotective clay, on experimental infectious diarrhoea in the rabbit. Current medical research and opinion. 8, 233-241.

- Roig J. L., Fuentes S., Colomina M. T., Vicens P. and Domingo J. L.. 2006. Aluminum, restraint stress and aging: Behavioral effects in rats after 1 and 2 years of aluminum exposure. Toxicology 218:112-124.

- Ruby M.V., Davis A. J., Houston Kempton, John W. Drexler, Paul D. Bergstroms, 1992. Lead Bioavailability: Dissolution Kinetics under Simulated Gastric Conditions, Environmental Science and Technology, 26, 12421248

- Ruby M.V., Davis A., Schoof R., Eberle S., Sellstone C.M., 1996. Estimation of lead and arsenic bioavailability using a physiologically based extraction test, Environmental Science and Technology, 30: 422-430

- Ruby M.V., Schoof R., Brattin W., Goldade M., Post G., Harnois M., Mosby D.E., Casteel S.W., Berti W., Carpenter M., Edwards D., Cragin D., Chappell W.,1999. Advances in evaluating the oral bioaccessibility if inorganics in soil for use in human health risk assessment. Environmental Science and Technology, 33:36973705 
- Saathoff E., Olsen A., Kvalsvig J.D., Geissler P.W., 2002. Geophagy and its association with geohelminth infections in rural school children from Northern KwaZulu Natal, South Africa. Transactions of the Royal Society of Tropical Medicine and Hygiene 96, 485-490.

- Schroder Jackie L., Nicholas T. Basta, Jitao Si, 2003. In Vitro Gastrointestinal Method to Estimate Relative Bioavailable Cadmium in Contaminated Soil, Environmental Science and Technology, 37, 1365-1370

- Smith, B., Rawlins B. G., Cordeiro M. J. A. R., Hutchins M. G., Tiberindwa J. V., Sserunjogi L., Tomkins A. M., 2000. The bioaccessibility of essential and potentially toxic trace elements in tropical soils from Mukono district, Uganda. Journal of the Geological Society, 157, 885-891

- Taste J.P., Environnements sédimentaires et structuraux quaternaires du littoral du golfe de guinée (Côte d'Ivoire, Togo et Benin), Thèse de Doctorat (1979) n621, Bordeaux I (France)

- Tateo F., Summa V., Bonelli G. C., Bentivenga G., 2001. Mineralogy and geochemistry of herbalist's clays for internal use: simulation of the digestive process. Applied Clay Science 20, 97-109.

- Trivedi T. H., Daga G. L., Yeolekar M. E., 2005. Geophagia Leading to Hypokalemic Quadriparesis in A Postpartum Patient, Journal of the Association of Physicians of India, 53, 205-207

- Vermeer D. E., Ferrell R. E., 1985. Nigerian geophagical clay: a traditional antidiarrheal Pharmaceutical Science 227, 634-636.

- William A. House, 1999. Trace element bioavailability as exemplied by iron and zinc, Field Crops Research, $60,115-141$

- Williams L.B., 2017. Geomimicry: harnessing the antibacterial action of clays. Clay Minerals, 52, 1-24

- Wong M., Bundy D., Golden M., 1991. The rate of ingestion of Ascaris lumbricoides and Trichuris trichiura eggs in soil and its relationship to infection in two children's homes in Jamaica. Transactions of the Royal Society for Tropical Medicine and Hygiene 85, 89-91.

- Wragg J., Cave M.R., 2003. In-vitro methods for the measurement of the oral bioaccessibility of selected metals and metalloids in soils: A critical review. Environment Agency, R\&D Technical Report P5-062/TR/01. 